\title{
Deep-water Drilliinae, Cochlespirinae and Oenopotinae (Mollusca: Gastropoda: Turridae) from the Campos Basin, southeast Brazil
}

\author{
RAQUEL MEDEIROS ANDRADE FIGUEIRA and RICARDO SILVA ABSALÃO
}

Departamento de Zoologia, Instituto de Biologia, Centro de Ciências da Saúde, Universidade Federal do Rio de Janeiro, Ilha do Fundão, 21941-590 Rio de Janeiro, Rio de Janeiro, Brasil. E-mail: raquel@ffigueira.net

\begin{abstract}
SUMMARY: Samples of a soft-bottom community from the continental slope of Campos Basin, off southeast Brazil, were obtained between 2001 and 2003 by the Research Vessel "Astro-Garoupa" with a $0.25 \mathrm{~m}^{2}$ box corer or by dredging with a Charcot dredge. A total of 177 samples were taken at depths ranging from 700 to $1950 \mathrm{~m}$. Mollusks were present at all of the stations and among Gastropoda the Turridae showed the highest diversity. Within the family Cochlespirinae we found: Leucosyrinx tenoceras (Dall, 1889), L. verrillii (Dall, 1881), expanding the known distribution of the latter species farther south, and L.? subgrundifera (Dall, 1888), which is the first record of this species for the South Atlantic and the shallowest depth at which it has ever been found. Within the family Drilliinae we found Splendrillia centimata (Dall, 1889), also the first record of this species for the South Atlantic and its shallowest depth. Within the subfamily Oenopotinae we describe here three new species in the genus Oenopota Mörch, 1852: O. seraphina n. sp., O. diabula n. sp. and O. carioca n. sp.
\end{abstract}

Keywords: deep-water, Turridae, Leucosyrinx, Splendrillia, Oenopota, Southwestern Atlantic, Brazil.

RESUMEN: Drilliinae, Cochlespirinae y Oenopotinae (Mollusca: Gastropoda: Turridae) de aguas profundas DE La Cuenca de Campos, sudeste del Brasil. - Se estudiaron muestras de sustratos sedimentarios procedentes de 117 estaciones del talud continental de la Cuenca de Campos (sudeste de Brasil), obtenidas entre 2001 y 2003 por el Buque de Investigación Astro-Garoupa, con un "box-corer" de $0.25 \mathrm{~m}^{2} \mathrm{o}$ con draga de Charcot a profundidades comprendidas entre 700 y $1950 \mathrm{~m}$. Los moluscos estuvieron presentes en todas las estaciones y, entre los gasterópodos, la familia Turridae presentó la máxima diversidad. Se encontraron tres especies pertenecientes a la subfamilia Cochlespirinae: Leucosyrinx tenoceras (Dall, 1889), L. verrillii (Dall, 1881), extendiendo su rango de distribución conocido hacia el sur, y L.? subgrundifera (Dall, 1888), que se cita por primera vez en el Atlántico sur y en el rango batimétrico menos profundo conocido hasta la fecha. Otra de las especies encontradas pertenece a la subfamilia Drilliinae: Splendrillia centimata (Dall, 1889), que se cita, asimismo, por primera vez en el Atlántico sur y en el rango batimétrico más superficial conocido. Dentro de la subfamilia Oenopotinae, describimos tres nuevas especies del género Oenopota Mörch, 1852: O. seraphina n. sp., O. diabula n. sp. y O. carioca n. sp.

Palabras clave: batial, Turridae, Leucosyrinx, Splendrillia, Oenopota, Atlántico suroeste, Brasil.

\section{INTRODUCTION}

Turridae Swainson, 1840 is one of the most significant families of marine gastropods in number of species, with over 670 genera (Bouchet, 1990). According to the traditional classification of gastropods, Turridae constitutes the superfamily Conoidea Rafinesque, 1815, together with the families Conidae and Terebridae. Traditionally, Turridae is seen as one of the most taxonomically disconcerting families, and most of the proposed classifications for it are based entirely on characters of the shell and radula (Powell, 1966; Bouchet and Warén, 1980). More recently, Taylor et al. (1993) suggested a new classification for the Conoidea, with a substantial rearrangement of the taxa, based on characters of the shell, operculum and foregut anatomy. Thus, these authors transferred most of the turrid genera to the family Conidae, restricting 
TABLE 1. - Geographical data for stations sampled with a box-corer. $\mathrm{N}^{\mathrm{o}}$ specimens refers to those belonging to the studied subfamilies.

\begin{tabular}{|c|c|c|c|c|}
\hline Station & Coordinates & Depth & Date & No. specimens \\
\hline OP I \# 44 & $22^{\circ} 10^{\prime} 43^{\prime \prime} \mathrm{S}, 39^{\circ} 54^{\prime} 46^{\prime \prime} \mathrm{W}$ & $750 \mathrm{~m}$ & $10 / 12 / 2002$ & 842 \\
\hline OP I \# 45 & $22^{\circ} 10^{\prime} 54^{\prime \prime} \mathrm{S}, 39^{\circ} 52^{\prime} 19^{\prime \prime} \mathrm{W}$ & $1050 \mathrm{~m}$ & $10 / 12 / 2002$ & 30 \\
\hline OP I \# 49 & $22^{\circ} 04^{\prime} 34^{\prime \prime} \mathrm{S}, 39^{\circ} 54^{\prime} 05^{\prime \prime} \mathrm{W}$ & $750 \mathrm{~m}$ & $24 / 11 / 2002$ & 63 \\
\hline OP I \# 50 & $22^{\circ} 04^{\prime} 33^{\prime \prime} \mathrm{S}, 39^{\circ} 52^{\prime} 04^{\prime \prime} \mathrm{W}$ & $1050 \mathrm{~m}$ & 24/11/2002 & 1 \\
\hline OP I \# 54 & $21^{\circ} 57^{\prime} 17^{\prime \prime} \mathrm{S}, 39^{\circ} 56^{\prime} 01^{\prime \prime \mathrm{W}}$ & $750 \mathrm{~m}$ & $12 / 12 / 2002$ & 21 \\
\hline OP I \# 59 & $21^{\circ} 52^{\prime} 59^{\prime \prime} \mathrm{S}, 39^{\circ} 55^{\prime} 30^{\prime \prime} \mathrm{W}$ & $750 \mathrm{~m}$ & $12 / 12 / 2002$ & 311 \\
\hline OP I \# 60 & $21^{\circ} 52^{\prime} 50^{\prime \prime} \mathrm{S}, 39^{\circ} 51^{\prime} 42^{\prime \prime} \mathrm{W}$ & $1050 \mathrm{~m}$ & $12 / 12 / 2002$ & 13 \\
\hline OP I \# 61 & $21^{\circ} 52^{\prime} 51^{\prime \prime} \mathrm{S}, 39^{\circ} 48^{\prime} 11^{\prime \prime} \mathrm{W}$ & $1350 \mathrm{~m}$ & $12 / 12 / 2002$ & 15 \\
\hline OP I \# 64 & $22^{\circ} 36^{\prime} 03$ ”'S, $40^{\circ} 21^{\prime} 45^{\prime \prime} \mathrm{W}$ & $750 \mathrm{~m}$ & $22 / 11 / 2002$ & 12 \\
\hline OP I \# 74 & $22^{\circ} 27^{\prime} 31^{\prime \prime S}, 40^{\circ} 09^{\prime} 23^{\prime \prime} \mathrm{W}$ & $750 \mathrm{~m}$ & $21 / 11 / 2002$ & 54 \\
\hline OP I \# 75 & $22^{\circ} 31^{\prime} 28^{\prime \prime} \mathrm{S}, 40^{\circ} 03^{\prime} 50^{\prime \prime} \mathrm{W}$ & $1050 \mathrm{~m}$ & $19 / 11 / 2002$ & 42 \\
\hline OP I \# 80 & $22^{\circ} 24^{\prime} 31^{\prime \prime S}, 39^{\circ} 57^{\prime} 28^{\prime \prime} \mathrm{W}$ & $1050 \mathrm{~m}$ & $20 / 11 / 2002$ & 15 \\
\hline OP I \# 84 & $22^{\circ} 26^{\prime} 27^{\prime \prime} \mathrm{S}, 39^{\circ} 58^{\prime} 51^{\prime \prime \mathrm{W}}$ & $1050 \mathrm{~m}$ & $20 / 11 / 2002$ & 1 \\
\hline OP I \# 85 & $22^{\circ} 29^{\prime} 33^{\prime \prime} \mathrm{S}, 39^{\circ} 56^{\prime} 17^{\prime \prime} \mathrm{W}$ & $1350 \mathrm{~m}$ & $19 / 11 / 2002$ & 6 \\
\hline OP II \# 44 & $22^{\circ} 10^{\prime} 43^{\prime \prime} \mathrm{S}, 39^{\circ} 54^{\prime} 45^{\prime \prime} \mathrm{W}$ & $750 \mathrm{~m}$ & $01 / 07 / 2003$ & 32 \\
\hline OP II \# 45 & $22^{\circ} 10^{\prime} 53^{\prime \prime} \mathrm{S}, 39^{\circ} 52^{\prime} 18^{\prime \prime} \mathrm{W}$ & $1039 \mathrm{~m}$ & $01 / 07 / 2003$ & 106 \\
\hline OP II \# 49 & $22^{\circ} 04^{\prime} 32^{\prime \prime} \mathrm{S}, 39^{\circ} 54^{\prime} 11^{\prime \prime} \mathrm{W}$ & $722 \mathrm{~m}$ & $30 / 06 / 2003$ & 25 \\
\hline OP II \# 54 & $21^{\circ} 57^{\prime} 11^{\prime \prime} \mathrm{S}, 39^{\circ} 56^{\prime} 04^{\prime \prime} \mathrm{W}$ & $698 \mathrm{~m}$ & 29/06/2003 & 40 \\
\hline OP II \# 58 & $21^{\circ} 57^{\prime} 26^{\prime \prime} \mathrm{S}, 39^{\circ} 40^{\prime} 34^{\prime \prime} \mathrm{W}$ & $1942 \mathrm{~m}$ & $27 / 06 / 2003$ & 2 \\
\hline OP II \# 59 & $21^{\circ} 52^{\prime} 59^{\prime \prime} \mathrm{S}, 39^{\circ} 55^{\prime} 32^{\prime \prime} \mathrm{W}$ & $751 \mathrm{~m}$ & $29 / 06 / 2003$ & 23 \\
\hline OP II \# 60 & $21^{\circ} 52^{\prime} 49^{\prime \prime} \mathrm{S}, 39^{\circ} 51^{\prime} 40^{\prime \prime} \mathrm{W}$ & $1055 \mathrm{~m}$ & $28 / 06 / 2003$ & 13 \\
\hline OP II \# 61 & $21^{\circ} 52^{\prime} 51^{\prime \prime} \mathrm{S}, 39^{\circ} 48^{\prime} 12^{\prime \prime} \mathrm{W}$ & $1372 \mathrm{~m}$ & $26 / 06 / 2003$ & 5 \\
\hline OP II \# 63 & $21^{\circ} 52^{\prime} 43^{\prime \prime S}, 39^{\circ} 40^{\prime} 41^{\prime \prime} \mathrm{W}$ & $1941 \mathrm{~m}$ & $26 / 06 / 2003$ & 1 \\
\hline OP II \# 69 & $22^{\circ} 31$ '11"S, $40^{\circ} 15$ ' $12^{\prime \prime} \mathrm{W}$ & $743 \mathrm{~m}$ & $18 / 06 / 2003$ & 7 \\
\hline OP II \# 74 & $22^{\circ} 27^{\prime} 31^{\prime \prime S}, 40^{\circ} 09^{\prime} 23^{\prime \prime} \mathrm{W}$ & $749 \mathrm{~m}$ & $18 / 06 / 2003$ & 88 \\
\hline OP II \# 75 & $22^{\circ} 31^{\prime} 28^{\prime \prime} \mathrm{S}, 40^{\circ} 03^{\prime} 49^{\prime \prime} \mathrm{W}$ & $1043 \mathrm{~m}$ & $18 / 06 / 2003$ & 29 \\
\hline OP II \# 79 & $22^{\circ} 20^{\prime} 22^{\prime \prime} \mathrm{S}, 40^{\circ} 01^{\prime} 24^{\prime \prime} \mathrm{W}$ & $755 \mathrm{~m}$ & $21 / 06 / 2003$ & 8 \\
\hline OP II \# 80 & $22^{\circ} 24^{\prime} 30^{\prime \prime} \mathrm{S}, 39^{\circ} 57^{\prime} 28^{\prime \prime} \mathrm{W}$ & $1044 \mathrm{~m}$ & $20 / 06 / 2003$ & 22 \\
\hline OP II \# 81 & $22^{\circ} 26^{\prime} 28^{\prime \prime} \mathrm{S}, 39^{\circ} 54^{\prime} 08^{\prime \prime} \mathrm{W}$ & $1345 \mathrm{~m}$ & $21 / 06 / 2003$ & 1 \\
\hline OP II \# 84 & $22^{\circ} 26^{\prime} 28^{\prime \prime} \mathrm{S}, 39^{\circ} 58^{\prime} 53^{\prime \prime} \mathrm{W}$ & $1046 \mathrm{~m}$ & $20 / 06 / 2003$ & 25 \\
\hline OP II \# 85 & $22^{\circ} 30^{\prime} 21^{\prime \prime S}, 39^{\circ} 56^{\prime} 53^{\prime \prime} \mathrm{W}$ & $1353 \mathrm{~m}$ & $21 / 06 / 2003$ & 1 \\
\hline OP II \# 86 & $22^{\circ} 31^{\prime} 37^{\prime \prime} \mathrm{S}, 39^{\circ} 55^{\prime} 14^{\prime \prime \mathrm{W}}$ & $1630 \mathrm{~m}$ & $16 / 06 / 2003$ & 2 \\
\hline B \# 32M & $22^{\circ} 38^{\prime} 01^{\prime \prime S}, 40^{\circ} 17^{\prime} 26^{\prime \prime} \mathrm{W}$ & $900 \mathrm{~m}$ & $18 / 05 / 2002$ & 5 \\
\hline
\end{tabular}

TABLE 2. - Geographical data for stations sampled with a Charcot dredge. $\mathrm{N}^{\circ}$ specimens refers to those belonging to the studied subfamilies.

\begin{tabular}{|c|c|c|c|c|}
\hline Sample & Coordinates & depth & date & No. specimens \\
\hline OP I \# 1 & $22^{\circ} 45^{\prime} \mathrm{S}, 40^{\circ} 10^{\prime} \mathrm{W}-22^{\circ} 42^{\prime} \mathrm{S}, 40^{\circ} 07^{\prime} \mathrm{W}$ & $1322-1326 \mathrm{~m}$ & $10 / 02 / 2003$ & 3 \\
\hline OP I \# 2 & $22^{\circ} 30^{\prime} \mathrm{S}, 40^{\circ} 00^{\prime} \mathrm{W}-22^{\circ} 28^{\prime} \mathrm{S}, 39^{\circ} 58^{\prime} \mathrm{W}$ & $1122-1147 \mathrm{~m}$ & $08 / 02 / 2003$ & 31 (1 live) \\
\hline OP I \# 3 & $22^{\circ} 35^{\prime} \mathrm{S}, 39^{\circ} 58^{\prime} \mathrm{W}-2^{\circ} 32^{\prime} \mathrm{S}, 39^{\circ} 56^{\prime} \mathrm{W}$ & $1620-1623 \mathrm{~m}$ & $11 / 02 / 2003$ & 5 \\
\hline OP I \# 4 & $22^{\circ} 24^{\prime} \mathrm{S}, 39^{\circ} 55^{\prime} \mathrm{W}-22^{\circ} 21^{\prime} \mathrm{S}, 39^{\circ} 53^{\prime} \mathrm{W}$ & $1128-1135 \mathrm{~m}$ & $07 / 02 / 2003$ & 2 \\
\hline OP I \# 5 & $22^{\circ} 27^{\prime} \mathrm{S}, 39^{\circ} 54^{\prime} \mathrm{W}-22^{\circ} 24^{\prime} \mathrm{S}, 39^{\circ} 52^{\prime} \mathrm{W}$ & $1320-1299 \mathrm{~m}$ & $08 / 02 / 2003$ & 2 \\
\hline OP I \# 7 & $22^{\circ} 45^{\prime} \mathrm{S}, 40^{\circ} 19^{\prime} \mathrm{W}-22^{\circ} 44^{\prime} \mathrm{S}, 40^{\circ} 16^{\prime} \mathrm{W}$ & $1118-1130 \mathrm{~m}$ & $09 / 02 / 2003$ & 10 \\
\hline OP I \# 8 & $22^{\circ} 48^{\prime} \mathrm{S}, 40^{\circ} 15^{\prime} \mathrm{W}-22^{\circ} 47^{\prime} \mathrm{S}, 40^{\circ} 13^{\prime} \mathrm{W}$ & $1324-1321 \mathrm{~m}$ & $11 / 02 / 2003$ & 5 (1 live) \\
\hline OP I \# 9 & $22^{\circ} 41^{\prime} \mathrm{S}, 40^{\circ} 02^{\prime} \mathrm{W}-22^{\circ} 39^{\prime} \mathrm{S}, 40^{\circ} 01^{\prime} \mathrm{W}$ & $1609-1621 \mathrm{~m}$ & $10 / 02 / 2003$ & 7 \\
\hline OP I \# 10 & $22^{\circ} 11^{\prime} \mathrm{S}, 39^{\circ} 51^{\prime} \mathrm{W}-22^{\circ} 08^{\prime} \mathrm{S}, 39^{\circ} 51^{\prime} \mathrm{W}$ & $1144-1127 \mathrm{~m}$ & $12 / 02 / 2003$ & 8 \\
\hline OP I \# 11 & $22^{\circ} 11^{\prime} \mathrm{S}, 39^{\circ} 49^{\prime} \mathrm{W}-22^{\circ} 09^{\prime} \mathrm{S}, 39^{\circ} 48^{\prime} \mathrm{W}$ & $1334-1327 \mathrm{~m}$ & $13 / 02 / 2003$ & 5 (1 live) \\
\hline OP I \# 12 & $22^{\circ} 11^{\prime} \mathrm{S}, 39^{\circ} 47^{\prime} \mathrm{W}-22^{\circ} 08^{\prime} \mathrm{S}, 39^{\circ} 46^{\prime} \mathrm{W}$ & $1632-1620 \mathrm{~m}$ & $12 / 02 / 2003$ & 4 \\
\hline OP I \# 13 & $21^{\circ} 53^{\prime} \mathrm{S}, 39^{\circ} 51^{\prime} \mathrm{W}-21^{\circ} 50^{\prime} \mathrm{S}, 39^{\circ} 52^{\prime} \mathrm{W}$ & $1120-1060 \mathrm{~m}$ & $14 / 02 / 2003$ & 38 \\
\hline OP I \# 14 & $21^{\circ} 50^{\prime} \mathrm{S}, 39^{\circ} 49^{\prime} \mathrm{W}-21^{\circ} 47^{\prime} \mathrm{S}, 39^{\circ} 50^{\prime} \mathrm{W}$ & $1358-1498 \mathrm{~m}$ & $14 / 02 / 2003$ & 7 \\
\hline OP I \# 15 & $21^{\circ} 48^{\prime} \mathrm{S}, 39^{\circ} 48^{\prime} \mathrm{W}-21^{\circ} 45^{\prime} \mathrm{S}, 39^{\circ} 48^{\prime} \mathrm{W}$ & $1620-1598 \mathrm{~m}$ & $13 / 02 / 2003$ & 5 \\
\hline OP I \# 16 & $22^{\circ} 15^{\prime} \mathrm{S}, 39^{\circ} 53^{\prime} \mathrm{W}-22^{\circ} 12^{\prime} \mathrm{S}, 39^{\circ} 52^{\prime} \mathrm{W}$ & $1071-1250 \mathrm{~m}$ & $13 / 02 / 2003$ & 26 (1 live) \\
\hline OP I \# 18 & $22^{\circ} 16^{\prime} \mathrm{S}, 39^{\circ} 47^{\prime} \mathrm{W}-22^{\circ} 13^{\prime} \mathrm{S}, 39^{\circ} 47^{\prime} \mathrm{W}$ & $1628-1622 \mathrm{~m}$ & $12 / 02 / 2003$ & 19 ( 1 live) \\
\hline OP II \# 1 & $22^{\circ} 41^{\prime} \mathrm{S}, 40^{\circ} 07^{\prime} \mathrm{W}-22^{\circ} 44^{\prime} \mathrm{S}, 40^{\circ} 10^{\prime} \mathrm{W}$ & $1318-1305 \mathrm{~m}$ & $27 / 08 / 2003$ & 1 \\
\hline OP II \# 2 & $22^{\circ} 30^{\prime} \mathrm{S}, 40^{\circ} 00^{\prime} \mathrm{W}-22^{\circ} 28^{\prime} \mathrm{S}, 39^{\circ} 58^{\prime} \mathrm{W}$ & $1107-1141 \mathrm{~m}$ & $27 / 08 / 2003$ & 4 (1 live) \\
\hline OP II \# 3 & $22^{\circ} 32^{\prime} \mathrm{S}, 39^{\circ} 56^{\prime} \mathrm{W}-22^{\circ} 35^{\prime} \mathrm{S}, 39^{\circ} 57^{\prime} \mathrm{W}$ & $1605-1605 \mathrm{~m}$ & $27 / 08 / 2003$ & 4 (1 live) \\
\hline OP II \# 5 & $22^{\circ} 27^{\prime} \mathrm{S}, 39^{\circ} 54^{\prime} \mathrm{W}-22^{\circ} 24^{\prime} \mathrm{S}, 39^{\circ} 52^{\prime} \mathrm{W}$ & $1325-1290 \mathrm{~m}$ & $25 / 08 / 2003$ & 7 \\
\hline OP II \# 7 & $22^{\circ} 46^{\prime} \mathrm{S}, 40^{\circ} 20^{\prime} \mathrm{W}-22^{\circ} 44^{\prime} \mathrm{S}, 40^{\circ} 17^{\prime} \mathrm{W}$ & $1107-1114 \mathrm{~m}$ & $28 / 08 / 2003$ & 2 \\
\hline OP II \# 8 & $22^{\circ} 49^{\prime} \mathrm{S}, 40^{\circ} 16^{\prime} \mathrm{W}-22^{\circ} 47^{\prime} \mathrm{S}, 40^{\circ} 13^{\prime} \mathrm{W}$ & $1305-1303 \mathrm{~m}$ & $28 / 08 / 2003$ & 5 \\
\hline OP II \# 10 & $22^{\circ} 11^{\prime} \mathrm{S}, 39^{\circ} 51^{\prime} \mathrm{W}-22^{\circ} 08^{\prime} \mathrm{S}, 39^{\circ} 51^{\prime} \mathrm{W}$ & $1157-1128 \mathrm{~m}$ & $22 / 08 / 2033$ & 13 \\
\hline OP II \# 11 & $22^{\circ} 11^{\prime}$ 'S, $39^{\circ} 49^{\prime} \mathrm{W}-22^{\circ} 08^{\prime}$ 'S, $39^{\circ} 48^{\prime} \mathrm{W}$ & $1332-1325 \mathrm{~m}$ & $22 / 08 / 2003$ & 8 (3 live) \\
\hline OP II \# 12 & $22^{\circ} 12^{\prime} \mathrm{S}, 39^{\circ} 47^{\prime} \mathrm{W}-2^{\circ} 08^{\prime} \mathrm{S}, 39^{\circ} 46^{\prime} \mathrm{W}$ & $1532-1640 \mathrm{~m}$ & $24 / 08 / 2003$ & 6 (1 live) \\
\hline OP II \# 13-1 & $21^{\circ} 53^{\prime} \mathrm{S}, 39^{\circ} 51^{\prime} \mathrm{W}-21^{\circ} 47^{\prime} \mathrm{S}, 39^{\circ} 52^{\prime} \mathrm{W}$ & $1064-1114 \mathrm{~m}$ & $20 / 08 / 2003$ & 23 (5 live) \\
\hline OP II \# 13-2 & $21^{\circ} 53^{\prime} \mathrm{S}, 39^{\circ} 51^{\prime} \mathrm{W}-21^{\circ} 49^{\prime} \mathrm{S}, 39^{\circ} 52^{\prime} \mathrm{W}$ & $1077-1082 \mathrm{~m}$ & $20 / 08 / 2003$ & 31 (5 live) \\
\hline OP II \# 14 & $21^{\circ} 50^{\prime} \mathrm{S}, 39^{\circ} 48^{\prime} \mathrm{W}-21^{\circ} 47^{\prime} \mathrm{S}, 39^{\circ} 50^{\prime} \mathrm{W}$ & $1360-1346 \mathrm{~m}$ & $21 / 08 / 2003$ & 4 \\
\hline OP II \# 15 & $21^{\circ} 50^{\prime} \mathrm{S}, 39^{\circ} 47^{\prime} \mathrm{W}-21^{\circ} 46^{\prime} \mathrm{S}, 39^{\circ} 48^{\prime} \mathrm{W}$ & $1664-1577 \mathrm{~m}$ & $21 / 08 / 2003$ & 1 \\
\hline OP II \# 16 & $22^{\circ} 16^{\prime} \mathrm{S}, 39^{\circ} 53^{\prime} \mathrm{W}-22^{\circ} 13^{\prime} \mathrm{S}, 39^{\circ} 52^{\prime} \mathrm{W}$ & $1059-1110 \mathrm{~m}$ & $22 / 08 / 2003$ & 107 (16 live) \\
\hline OP II \# 17-1 & $22^{\circ} 15^{\prime} \mathrm{S}, 39^{\circ} 51^{\prime} \mathrm{W}-22^{\circ} 12^{\prime} \mathrm{S}, 39^{\circ} 49^{\prime} \mathrm{W}$ & $1332-1300 \mathrm{~m}$ & $23 / 08 / 2003$ & 3 \\
\hline OP II \# 17-2 & $22^{\circ} 16^{\prime} \mathrm{S}, 39^{\circ} 51^{\prime} \mathrm{W}-22^{\circ} 12^{\prime} \mathrm{S}, 39^{\circ} 49^{\prime} \mathrm{W}$ & $1332-1264 \mathrm{~m}$ & $24 / 08 / 2003$ & 2 \\
\hline OP II \# 18 & $22^{\circ} 15^{\prime} \mathrm{S}, 39^{\circ} 47^{\prime} \mathrm{W}-22^{\circ} 12^{\prime} \mathrm{S}, 39^{\circ} 47^{\prime} \mathrm{W}$ & $1620-1618 \mathrm{~m}$ & $23 / 08 / 2003$ & 4 (1 live) \\
\hline
\end{tabular}


Turridae to only a few of them. This taxonomic suggestion was followed by Bouchet and Rocroi (2005); however, Rosenberg (1998) noted several misinterpretations in that analysis and recommended that the more traditional classification should not be abandoned just yet. Recently, Puillandre et al. (2008) provided a molecular phylogeny of the "turrids". However, we prefer to follow Rosenberg and the "traditional" taxonomic arrangement of Turridae until a more definitive taxonomic framework is established. Tucker (2004) organized a list of turrids of the world, but did not discuss generic or specific allocations.

The family Turridae was first divided into three subfamilies (Turritinae, Clavatulinae and Defranciinae) by H. and A. Adams (1858). Since then this subdivision has been revised and discussed repeatedly, and many other subfamilies have been proposed. Rosenberg (2005) mentioned 12 subfamilies within Turridae, Powell (1966) recognized only 9, and Bouchet and Warén (1980) disregarded this separation altogether. Although the classification of the Turridae at the subfamily level is still very much debated and some of the taxa may be artificial, we agree with Kilburn (1983) that "in a family as large and complex as Turridae, virtually any practical subdivision is better than none".

There are few records of the deep-water species from the Brazilian coast, and only after the second half of the twentieth century have they begun to increase slowly: e.g. Leal and Bouchet (1989, 1991), Leal and Rios (1990), and Leal and Simone (1998, 2000). Other reports have appeared, such as Absalão et al. (2001, 2005), Absalão and Pimenta (2003), Absalão and Santos (2004), Zelaya et al. (2006), Simone (1999, 2002, 2003), Simone and Birman (2006), Simone and Cunha (2006), Barros et al. (2007), Lima and Barros (2007), and Lima et al. (2007). However, only Absalão et al. (2005) dealt with Turridae.

The goal of the present study was to revise the Brazilian deep-water Drilliinae, Cochlespirinae and Oenopotinae from the Campos Basin in the state of Rio de Janeiro, the main oil production region in Brazil. The study is part of a large project on Brazilian deep-water mollusks.

\section{MATERIALS AND METHODS}

The mollusks were taken from the southern coast of Brazil (700-1950 m depth). The sampling stations were in the Bacia de Campos (Campos Basin) and were visited as part of the program "Environmental Characterization of Campos Basin, RJ, Brazil". Samples were obtained by the Research Vessel "Astro-Garoupa" belonging to Petrobras S.A. (a public Brazilian oil company) with a $0.25 \mathrm{~m}^{2}$ box core or by dredging with a Charcot dredge. A total of 117 samples were taken in this region. Each sample was washed in running seawater through a mesh of $300 \mu \mathrm{m}$, and the residue placed in $70 \%$ ethanol. In the laboratory, this residue was sorted under magnification and the Turridae picked out. The analysis was based only on shell characters, since most of the material obtained consisted of empty shells. Types were not examined when the original illustration (and/or description) was sufficient to identify the taxon. All material is deposited in the Molluscan Collection of the Departamento de Zoologia, Instituto de Biologia of the Universidade Federal do Rio de Janeiro (IBUFRJ). Of the species described as new, additional paratypes were sent to the following institutions: $\mathrm{Mu}-$ seu de Zoologia da Universidade de São Paulo (MZSP) in São Paulo, Brazil; Museu Nacional (MNRJ) in Rio de Janeiro, Brazil; Muséum National d'Histoire Naturelle (MNHN) in Paris, France; and Museum of Comparative Zoology (MCZ) of the Harvard University, Massachusetts, United States.

Locations and data of the sampled stations are shown in Tables 1 and 2.

\section{RESULTS}

$$
\begin{gathered}
\text { Family TuRRIDAE Swainson, } 1840 \\
\text { Subfamily OENOPOTINAE } \\
\text { Genus Oenopota Mörch, } 1852
\end{gathered}
$$

Type species: Fusus pleurotomarius Couthouy, 1838 by subsequent designation Dall, 1918.

Oenopota seraphina $\mathrm{n}$. sp. (Fig. 1A, B, C)

Type material: Holotype IBUFRJ 18299 OP II \# 84 (22²6'28”'S, 39 58'53"W), $1046 \mathrm{~m}$ (Fig. 1A, C), $4.60 \mathrm{~mm}$. Paratypes MNRJ 13552 [5], $3.64 \mathrm{~mm}, 3.66 \mathrm{~mm}, 3.80 \mathrm{~mm}, 4.02 \mathrm{~mm}$ and $4.46 \mathrm{~mm}$, Paratypes MZSP 90704 [5], $3.72 \mathrm{~mm}, 3.98 \mathrm{~mm}, 4.16 \mathrm{~mm}, 4.18 \mathrm{~mm}$ and $4.72 \mathrm{~mm}$, Paratypes MNHN [5], $3.86 \mathrm{~mm}, 3.96 \mathrm{~mm}, 4.12 \mathrm{~mm}$, $4.16 \mathrm{~mm}$ and $5.36 \mathrm{~mm}$, Paratype MCZ 362494 [2], $3.96 \mathrm{~mm}$ (Fig. $1 \mathrm{~B})$ and $4.42 \mathrm{~mm}$, all from OP I \# 44 (22 $10^{\circ} 43^{\prime}$ 'S, 39 $\left.54^{\prime} 46^{\prime \prime} \mathrm{W}\right)$, 750 m. Paratypes MNRJ 13553 [4], $3.62 \mathrm{~mm}, 3.64 \mathrm{~mm}, 3.84 \mathrm{~mm}$ and $4.34 \mathrm{~mm}$, Paratypes MZUSP 90705 [4], $3.18 \mathrm{~mm}, 3.84 \mathrm{~mm}$, $4.12 \mathrm{~mm}$ and $4.32 \mathrm{~mm}$, Paratypes MCZ 362495 [4], $4.06 \mathrm{~mm}$, $4.12 \mathrm{~mm}, 4.60 \mathrm{~mm}$ and $5.34 \mathrm{~mm}$, all from OP I \# 59 (21 ${ }^{\circ} 52^{\prime} 59^{\prime \prime} \mathrm{S}$, $\left.39^{\circ} 55^{\prime} 30^{\prime} \mathrm{W}\right), 750 \mathrm{~m}$

Type locality: $22^{\circ} 26^{\prime} 28^{\prime \prime} \mathrm{S}, 39^{\circ} 58^{\prime} 53^{\prime \prime} \mathrm{W}$, Campos Basin, southeast Brazil, southwestern Atlantic, $1046 \mathrm{~m}$.

Material examined: Type material and 17213 [756] OP I \# 44; 18286 [8] OP I \# 45; 15033 [48] OP I \# 49; 14965 [21] OP I \# 54; 17047 [286] OP I \# 59; 18287 [1] OP I \# 60; 18288 [3] OP I \# 61; 16090 [11] OP I \# 64; 15351 [35] OP I \# 74; 18289 [13] OP I \# 75; 18290 [12] OP I \# 80; 18291 [1] OP I \# 84; 18292 [1] OP I \# 85; 18388 [179] OP II \# 44; 16962 [89] OP II \# 45; 18389 [46] OP II \# 49; 15569 [35] OP II \# 54; 18390 [248] OP II \# 59; 18293 [5] OP II \# 60; 15541 [3] OP II \# 69; 17273 [68] OP II \# 74; 18294 [10] OP II \# 75; 16806 [8] OP II \# 79; 18295 [19] OP II \# 80; 18296 [7] OP II \# 84; 18297 [1] OP II \# 85; 18298 [5] B \# 32M.

Description: Shell short, plump, white, with up to $5.3 \mathrm{~mm}$ (3 whorls) (Fig. 1A, B). Protoconch with about $11 / 2$ whorls, white, smooth, dome-shaped, with faint axial riblets on the last $1 / 2$ whorl (Fig. 1C). Teleoconch whorls with a concave region below the suture, forming an acute shoulder. Axial sculpture consists of about 16 orthocline ribs, forming small blunt nodules where they cross the shoulder and the area immediately below 


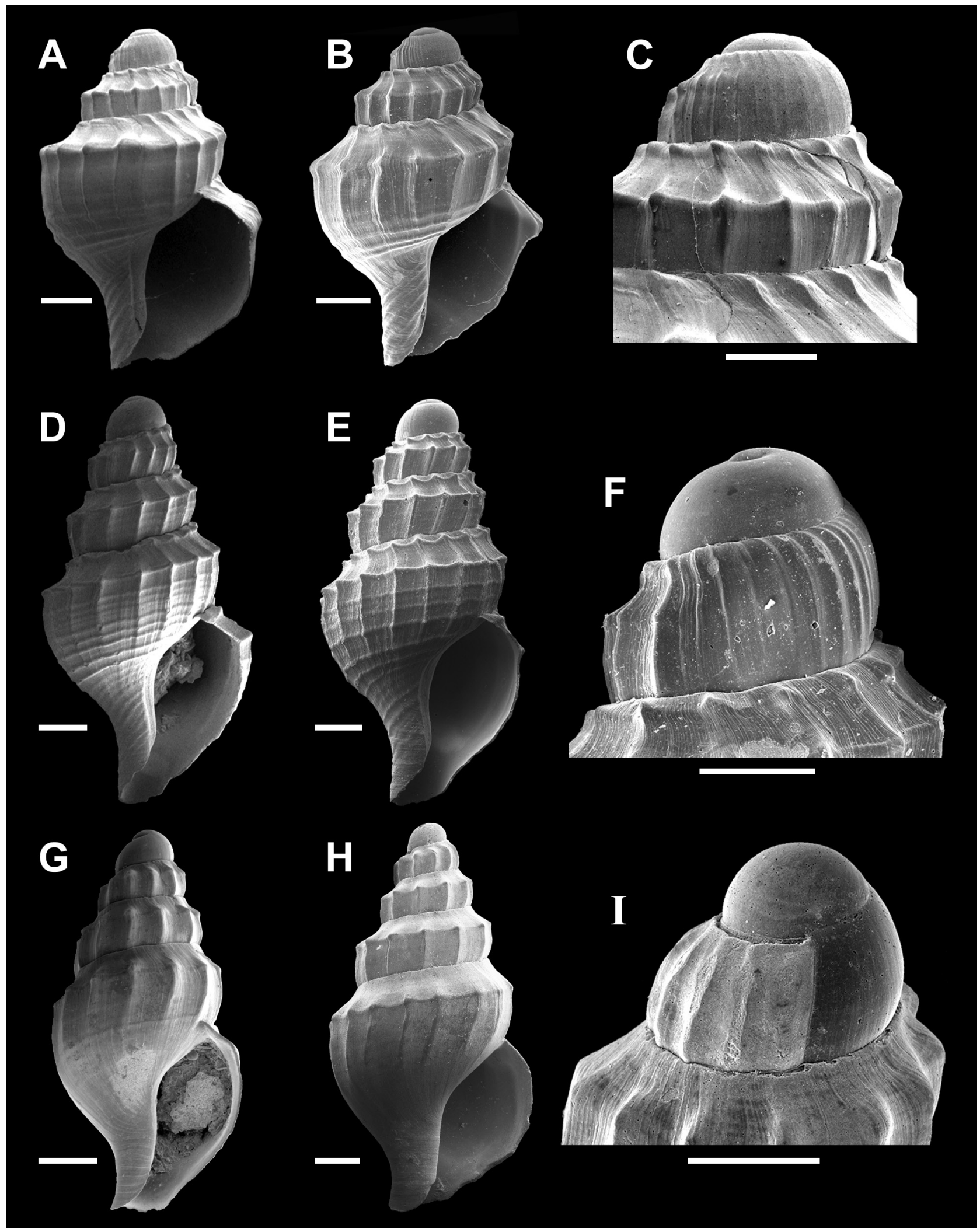

FIG. 1. - A, B, C, Oenopota seraphina n. sp.: A, C, holotype, IBUFRJ 18299, 4.6 mm; A, whole shell; C, protoconch; B, paratype, MCZ 362494, 3.96 mm, whole shell. D, E, F, O. diabula n. sp.: D, holotype, IBUFRJ 18300, $5.4 \mathrm{~mm}$, whole shell; E, paratype, MCZ $362496,5.54$ mm, whole shell; F, paratype, IBUFRJ 18301, protoconch. G, H, I, O. carioca $\mathrm{n}$. sp.: G, holotype, IBUFRJ 18303, $4.3 \mathrm{~mm}$, whole shell; H, paratype, MNRJ 13556, 5 mm, whole shell; I, paratype, IBUFRJ 18304, protoconch. Scale bars: A, B, D, E, G and H, $600 \mu \mathrm{m}$; C, F and I, $400 \mu \mathrm{m}$. 
the suture, and extend over the base, vanishing towards the inner lip. Suture moderately shallow. Base short, convex, inflecting to form a fasciolar region, sculptured with about 4 spiral cords. Fasciolar region with 6 oblique cords. No labial sinus. Inner lip reflected over parietal wall. Outer lip thin. Siphonal canal broad and short. Aperture ovoid-elliptical.

\section{Etymology: seraphina refers to a kind of angel.}

Geographic distribution: Only known from Campos Basin, off Rio de Janeiro, 698-1353 m.

Discussion: Bouchet and Warén (1980) considered Oenopota in a broad sense, including as synonyms 11 other generic names, admitting a wide range of variation both in the protoconch and in teleoconch sculpture and shape. Although Lundberg et al. (1996) provided cladistic results that indicate that Oenopota is a paraphyletic group, we will adopt the Oenopota concept of Bouchet and Warén (1980) until anatomical and/or molecular data become available.

There are five species of Oenopota assigned to the southwestern Atlantic region (Rosenberg, 2005; Forcelli, 2000): O. magellanica (Martens, 1881), O. profunda (Castellanos and Landoni, 1993), O. anomalapex (Powell, 1951), O. lateplicata (Strebel, 1905) and $O$. cunninghami (E.A. Smith, 1881).

Oenopota magellanica occurs in the south of Brazil at $32^{\circ} \mathrm{S}$ and geographically it is the closest species to Oenopota seraphina n. sp., but it is very distinct from it. Oenopota seraphina $\mathrm{n}$. sp. can be differed by its plump and shouldered profile, wide aperture, short anterior canal and spiral ornamentation restricted to the base. $O e$ nopota profunda has a type locality at $60^{\circ} \mathrm{S}$ and $600 \mathrm{~m}$ depth, O. seraphina n. sp. is quite different in its fewer and stronger axial ribs, spiral ornamentation restricted to the base, larger body whorl and strongly shouldered whorls. Oenopota anomalapex, another species from southern Argentinean Patagonia, can be distinguished from $O$. seraphina $\mathrm{n}$. sp. because the latter species has a nodulose subsutural cord, an angled shoulder and an inner lip reflected over the parietal wall. Finally, Oenopota lateplicata, a littoral species, has no trace of a sub-sutural cord, and the axial ribs are devoid of nodules at the whorl shoulder; both the shell and aperture are more slender, and there is a conspicuous anal sinus. Oenopota cunninghami is somewhat similar to O. seraphina n. sp. in the plump and shouldered profile and short anterior canal, but it has much more numerous spiral threads covering the entire whorl, a narrower aperture, the axial ribs are more sinuous and it is found in shallow water $(110-165 \mathrm{~m})$.

This species resembles Oenopota graphica (Locard, 1897) from Morocco and Spain, illustrated by Bouchet and Warén (1980, Figs. 152, 153), in the plump and shouldered profile, but O. seraphina $\mathrm{n}$. sp. has the spiral ornamentation restricted to the base and a longer siphonal canal and protoconch with fine spiral threads according to the photograph of Bouchet and Warén 1980, p. 104, Fig. 269. Oenopota seraphina n. sp. also shows a superficial similarity to Benthomangelia decapitata Bouchet and Warén (1980, p. 47, Figs. 107-108). However, O. seraphina n. sp. has more numerous axial ribs, spiral ornamentation restricted to the base and a very different protoconch.

Oenopota diabula n. sp. (Fig. 1D, E, F)

Type material: Holotype IBUFRJ 18300 OP I \# 44 (2210`43”S, $39^{\circ} 54^{\prime} 46^{\prime \prime} \mathrm{W}$ ), $750 \mathrm{~m}, 5.40 \mathrm{~mm}$ (Fig. 1D). Paratype IBUFRJ 18301 [1] OP II \# 45 (22॰10’53”S, 39॰52’18”W), 1039 m, 3.54 mm (Fig. 1F). Paratype MCZ 362496 [3] OP II \# 59, $4.70 \mathrm{~mm}, 4.88 \mathrm{~mm}$ and $5.54 \mathrm{~mm}$ (Fig. 1E), Paratype MNRJ 13554 [1], 4.08 mm, OP II \# 75. Paratype MNRJ 13555 [2], $3.58 \mathrm{~mm}$ and $7.20 \mathrm{~mm}$, Paratype MZSP 90707 [2], $3.24 \mathrm{~mm}$ and $5.52 \mathrm{~mm}$, Paratype MNHN [2], $3.90 \mathrm{~mm}$ and $5.18 \mathrm{~mm}$, all from OP II \# 84. Paratype MZSP 90706 [1], 4.90 $\mathrm{mm}$, Paratype MNHN [1], $4.46 \mathrm{~mm}$, all from OP I \# 75.

Type locality: $22^{\circ} 10^{\prime} 43^{\prime \prime} \mathrm{S}, 39^{\circ} 54^{\prime} 46^{\prime \prime} \mathrm{W}$, Campos Basin, southeast Brazil, southwestern Atlantic, $750 \mathrm{~m}$.

Material examined: Type material and 17203 [12] OP I \# 44; 18272 [20] OP I \# 45; 15035 [1] OP I \# 49; 18273 [1] OP I \# 50; 17048 [19] OP I \# 59; 18274 [12] OP I \# 60; 18275 [12] OP I \# 61; 15353 [2] OP I \# 74; 18276 [25] OP I \# 75; 18277 [3] OP I \# 80; 18278 [5] OP I \# 85; 18386 [6] OP II \# 44; 16961 [11] OP II \# 45; 18387 [5] OP II \# 59; 18279 [7] OP II \# 60; 18280 [5] OP II \# 61; 18281 [17] OP II \# 75; 18282 [3] OP II \# 80; 18283 [1] OP II \# 81; 18284 [11] OP II \# 84; 18285 [2] OP II \# 86.

Description: Shell short, white, with up to $7.2 \mathrm{~mm}$ (3 1/2 whorls) (Fig. 1D, E). Protoconch with one whorl, white, smooth, dome-shaped, with faint axial riblets on the last $1 / 4$ whorl (Fig. 1F). Teleoconch whorls with a slightly concave region between the suture and the shoulder. Spirally sculptured by a prominent thin cord on the shoulder, a weaker subsutural cord, and several thin threads on the lower portion of the whorls. From the whorl shoulder to the fasciolar region, the body whorl is sculptured with about 16-20 spiral threads. Axial sculpture consists of about 16 thin orthocline ribs forming small pointed sharp nodules where they cross the shoulder spiral cord and the subsutural one, and extend over the base, vanishing towards the inner lip. Suture moderately deep. Base short, convex, inflecting to form the fasciolar region. No labial sinus. Inner lip thin, reflected over the parietal wall. Outer lip thin. Siphonal canal broad and moderately short. Aperture elliptical.

Etymology: diabula refers to the feminine of "diabo" which is a spiritual entity from the Afro-Brazilian culture.

Geographical distribution: Only known from Campos Basin, off Rio de Janeiro, 750-1630 m.

Discussion: Oenopota diabula n. sp. can be distinguished from $O$. profunda, $O$. anomalapex, O. lateplicata and $O$. magellanica by its nodulose subsutural 
spiral cord and the presence of nodules on the whorl shoulder, both of which are lacking in the previously known species; and the weaker spiral ornamentation. It can also be distinguished from O. cunninghami by the nodulose subsutural spiral cord, longer siphonal canal and narrower aperture. Oenopota diabula n. sp. has a narrower shell than $O$. seraphina $\mathrm{n}$. sp., spiral threads on the anterior part of the whorls, and a narrower reflected inner lip. Oenopota diabula n. sp. resembles Oenopota graphica (Locard, 1897) from Morocco and Spain, illustrated by Bouchet and Warén (1980, Figs. $152,153)$, but it has a much longer siphonal canal and more numerous and weaker spiral threads. It is also similar to Oenopota rugulata (Troschel, 1866), from the Bering Sea and Norway, illustrated in Dall (1919, p. 50, pl. 13, Fig. 6), in the shouldered profile and longer siphonal canal, but it can be distinguished by its narrower reflected inner lip, the presence of a nodulose sub-sutural spiral cord, and the absence of any other spiral ornamentation above the whorl shoulder.

Oenopota diabula $\mathrm{n}$. sp. is superficially similar to Benthomangelia decapitata (Bouchet and Warén 1980, p. 47, Figs. 107-108), but it can be distinguished by its nodulose subsutural cord, absence of spiral threads above the shoulder, fewer spiral threads below the shoulder, slightly softer axial ribs and a very different protoconch.

\section{Oenopota carioca n. sp. (Fig. 1G, H, I)}

Type material: Holotype IBUFRJ 18303 OP I \# 74 (2227'31'’S, $40^{\circ} 09^{\prime} 23^{\prime} \mathrm{W}$ ), $750 \mathrm{~m}, 4.03 \mathrm{~mm}$ (Fig. 1G). Paratype MCZ 362497 [3], $3.42 \mathrm{~mm}, 3.6 \mathrm{~mm}$ and $3.96 \mathrm{~mm}$, Paratype MZSP 90708 [3], $2.72 \mathrm{~mm}, 3.92 \mathrm{~mm}$ and $4.48 \mathrm{~mm}$, Paratype MNHN [4], $2.36 \mathrm{~mm}$, $3.60 \mathrm{~mm}, 4.02 \mathrm{~mm}$ and $4.76 \mathrm{~mm}$, all from type locality. Paratype IBUFRJ 18304 [2], OP I \# 59 (2152'59”S, 39॰55'30”'W), 750 m, $2.2 \mathrm{~mm}$ (Fig. 1I) and $4.29 \mathrm{~mm}$. Paratype MNRJ 13556 [2] OP I \# 49, $2.56 \mathrm{~mm}$ and $5 \mathrm{~mm}$ (Fig. $1 \mathrm{H})$.

Type locality: $22^{\circ} 27^{\prime} 31^{\prime \prime S}, 40^{\circ} 09^{\prime} 23^{\prime \prime} \mathrm{W}$, Campos Basin, southeast Brazil, southwestern Atlantic, $750 \mathrm{~m}$.

Material examined: Type material and 17199 [62] OP I \# 44; 18269 [2] OP I \# 45; 15036 [12] OP I \# 49; 17044 [14] OP I \# 59; 16091 [1] OP I \# 64; 15354 [13] OP I \# 74; 18270 [3] OP I \# 75; 18383 [25] OP II \# 44; 18384 [25] OP II \# 49; 15570 [5] OP II \# 54; 18385 [14] OP II \# 59; 15543 [4] OP II \# 69; 17280 [19] OP II \# 74; 18271 [2] OP II \# 75

Description: Shell short, slender, white, with up to $5 \mathrm{~mm}$ (4 1/2 whorls) (Fig. 1G, H). Protoconch with one whorl, white, smooth. Clear-cut proto-teleoconch boundary (Fig. 1I). Teleoconch whorls with a very slightly concave region between the suture and the shoulder. Shoulder marked by a very faint spiral thread and another faint suprasutural thread is visible on the third whorl. Axial sculpture consists of about 14 ribs (on the third whorl), forming small gentle nodules on the shoulder and fading away above it, never reaching the suture. Growth scars over entire shell. Suture moderately shallow. Base smooth, short, convex gently inflecting to form the short fasciolar region. No labial sinus. Inner and outer lips thin. Siphonal canal broad, moderately short and slightly bent upward. Aperture elongated.

Etymology: carioca is the name for all those born in Rio de Janeiro.

Geographical distribution: Only known from Campos Basin, off Rio de Janeiro, 698-1050 m.

Discussion: Oenopota carioca n. sp. can be distinguished from $O$. magellanica by the presence of only two faint spiral threads, stronger shoulder and shorter siphonal canal. It can be differed from $O$. profunda by its narrower profile, stronger and fewer axial ribs, and the presence of only two faint spiral threads. Oenopota carioca n. sp. can be distinguished from $O$. anomalapex by its narrower shell, its orthocline axial ribs, and the presence of only two faint spiral threads. Oenopota carioca n. sp. shares its shell profile with $O$. lateplicata, but can be distinguished from it by its larger protoconch, the slight nodules where axial ribs cross the shoulder, and the presence of only two faint spiral threads. Oenopota cunninghami has the same profile, but $O$. carioca n. sp. has only two faint spiral threads and a slightly inflected siphonal canal.

Oenopota carioca n. sp. can be distinguished from $O$. seraphina by its narrower profile, fewer axial ribs, and the presence of two faint spiral threads on the whorls and smooth base. Oenopota carioca n. sp. shares with Oenopota diabula n. sp. the same general shell shape, but whereas Oenopota carioca n. sp. has gentle axial ribs and a rounded shoulder, Oenopota diabula $\mathrm{n}$. sp. has more acute axial ribs and small pointed sharp nodules on the shell shoulder. Also, Oenopota carioca $\mathrm{n}$. sp. has only two faint spiral threads

\section{Subfamily CochlesPIRINAE Genus Leucosyrinx Dall, 1889}

Type-species: Pleurotoma verrilli Dall, 1881

Leucosyrinx verrillii (Dall, 1881) (Fig. 2A, B, C)

Pleurotoma (Pleurotomella) verrillii Dall, 1881: 57. Pleurotoma (Pleurotomella?) sigsbei Dall, 1881: 57: Abbott (1974: 263, Fig. 2899).

Pleurotoma (Leucosyrinx) verrillii: Dall (1889: 75, pl. X, Fig. 5); Dall (1890: 302).

Pleurotoma talismani Locard, 1897: Dautzenberg (1927: 28, pl. II, Fig.1); Dautzenberg and Fischer (1906: 10).

Surcula gradata Thiele, 1925: 211 [177], pl. XXXV [XXXIII], Fig. 13-15.

Leucosyrinx janetae Bartsch, 1934: 11, pl. 3, Fig. 3, 11, 12: Powell (1966: pl. 2, Fig. 7)

Leucosyrinx sigsbeei error pro sigsbei: Dall (1903: 96) Powell (1966: 30).

Leucosyrinx verrillii: Mendiskaya (1999: 175, Fig. 2); Thiele (1931: 358); Powell (1966: 30, pl. 2, Fig. 6); Abbott (1974: 263, Fig. 2898); Bouchet and Warén (1980: 23, Figs. 8, 68, 69, 197, 202); Rios (1975: 128, pl. 39, Fig. 565; 1985: 133, pl. 45, Fig. 601; 1994: 166, pl. 55, Fig. 754). 


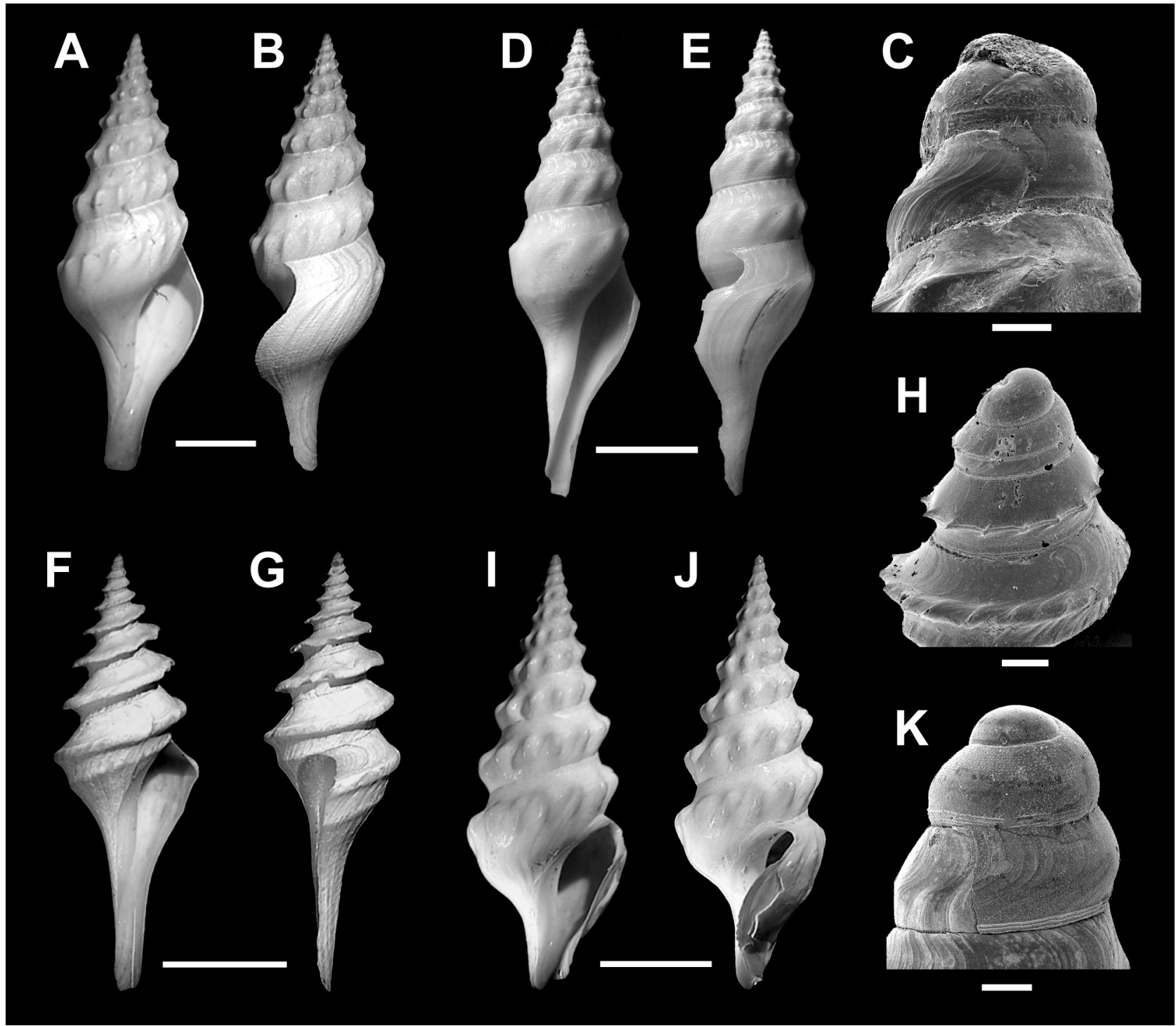

FIG. 2. - A, B, C, Leucosyrinx verrillii (Dall, 1881): A, B, IBUFRJ 16527, 30.16 mm, whole shell; C, IBUFRJ 16681, protoconch. D, E, L. tenoceras (Dall, 1889), IBUFRJ 16422, $52.01 \mathrm{~mm}$, whole shell. F, G, H, L. ? subgrundifera (Dall, 1888): F, G, IBUFRJ $16705,19.82$ mm, whole shell; H, IBUFRJ 18267, protoconch. I, J, K, Splendrillia centimata (Dall, 1889): I, J, IBUFRJ 18263, 21.83 mm; K, IBUFRJ 18262, protoconch. Scale bars: A, B, F, G, I and J, $5 \mathrm{~mm}$; D and E, $10 \mu \mathrm{m} ; \mathrm{C}, \mathrm{H}$ and K, $200 \mu \mathrm{m}$.

Type material: Holotype MCZ 007032, Blake sta $41\left(23^{\circ} \mathrm{N}, 83^{\circ} \mathrm{W}\right)$, off Bahia Honda, Cuba, 1572 m. (not examined).

Material examined: 16401 [1] OP I \# 1; 16420 [26] OP I \# 2; 16435 [1] OP I \# 2; 16398 [5] OP I \# 3; 16444 [2] OP I \# 4; 16412 [10] OP I \# 7; 16452 [1] OP I \# 9; 16425 [2] OP I \# 10; 16443 [6] OP I \# 10; 16515 [36] OP I \# 13; 16465 [3] OP I \# 14; 16468 [1] OP I \# $15 ; 16510$ [24] OP I \# 16; 16442 [1] OP I \# 18; 16669 [1] OP II \# $1 ; 16578$ [2] OP II \# 2; 16524 [6] OP II \# 5; 16527 [2] OP II \# 7; 16384 [3] OP II \# 8; 16530 [13] OP II \# 10; 16549 [6, 2 live] OP II \# 11; 16518 [2] OP II \# 13-1; 16522 [21, 5 live] OP II \# 13-1; 16612 [16] OP II \# 13-2; 16548 [14, 5 live] OP II \# 13-2; 16390 [2] OP II \# 14; 16587 [1] OP II \# 15; 16520 [93, 16 live] OP II \# 16; 16681 [3] OP II \# 16; 16650 [1] OP II \# 17-1; 16533 [1] OP II \# 17-2; 1826 [1] OP II \# 60.

Description: Shell high, slender, whitish, with 9 whorls (Fig. 2A, B). Protoconch with three whorls, dark yellow, smooth except for very fine supra-sutural spi- ral threads (Fig. 2C). Teleoconch whorls pagoda-like, showing a slightly concave region between the suture and the shoulder. Whorls sculptured with large, blunt, axially elongated nodules, beginning on their shoulder and continuing towards the inferior suture, about 14 on the $7^{\text {th }}$ whorl, and numerous fine spiral threads over the entire shell. Suture shallow. Base concave, with spiral threads on its upper half and smooth on its lower half. Labial sinus broad and moderately shallow. Inner lip reflected. Outer lip projecting forward. Siphonal canal long and wide. Aperture elliptical.

Geographical distribution: Northwest Atlantic: North Carolina, Florida, Gulf of Mexico, West Indies (Dall, 1889; Dall, 1903); West Indies (Dall, 1890; Medinskaya, 1999; Bartsch, 1934). Southwest At- 
lantic: Bahia (Dall, 1890); Campos Basin, southeast Brazil (this paper). Northeast Atlantic: Azores and Morocco (Dautzenberg, 1927); Morocco and Canary Islands (Dautzenberg and Fischer, 1906); Côte d'Ivoire (Thiele, 1925); Spain, Portugal, Morocco, Mauritania, Azores, Madeira, Canary Islands, Cape Verde (Bouchet and Warén, 1980).

Bathymetry: from $274 \mathrm{~m}$ (Dall, 1889) to $3030 \mathrm{~m}$ (Bouchet and Warén, 1980).

Discussion: Leucosyrinx was described by Dall (1889: 75), as a subgenus of Pleurotoma Lamarck, 1799 , to include the operculated species characteristic of the archibenthic zone. According to Dall, these species differ from all others by their thin, white, delicately sculptured shells, lack of a subtubular projection of the anal notch, lack of a thick varix to mark their maturity, generally large size, long siphonal canal and wide rounded anal sinus close to the suture.

Our material matches with the original illustration (Dall, 1889, pl. X, Fig. 5) and description (Dall, 1881, p. 57). Leucosyrinx verrillii as figured by Bouchet and Warén (1980: 24, Fig. 68) seems to be the same. Our material differs from these by its narrower posterior part of the aperture. Gracia et al. (2004, p. 65, Fig. 53) also illustrated the same species from the Colombian continental slope, but the teleoconch and the aperture are narrower and the siphonal canal is longer than both our and Bouchet and Warén's (1980) material. In fact, Gracia's material is more similar to L. tenoceras (Dall, 1889) (see below).

\section{Leucosyrinx tenoceras (Dall, 1889)} (Fig. 2D, E)

\footnotetext{
Pleurotoma (Leucosyrinx) tenoceras Dall, 1889: 76, pl. XXXVI, Fig. 5: Dall (1890: 302).

Leucosyrinx tenoceras: Powell (1966: 30); Abbott (1974: 263, Fig. 2897); Rios (1975: 128, pl. 39, Fig. 564; 1985: 132, pl. 45, Fig. 600; 1994: 166, pl. 55, Fig. 753).

Leucosyrinx verrillii: Gracia et al. (2004: 66, Fig. 53).
}

Type material: Syntype MCZ 007036, Blake sta 161, near Guadalupe, 1066m. Syntype MCZ 007037, Blake sta 265, near Grenada, $1053 \mathrm{~m}$. (not examined).

Material examined: 16432 [1] OP I \# 2; 16422 [1 live] OP I \# 8; 16428 [1] OP I \# 11; 16543 [1] OP II \# 16; 16544 [1] OP II \# 17-2.

Description: Shell high, slender, whitish, with 10 whorls (Fig. 2D, E). Protoconch with three darkyellow whorls with fine spiral threads. Teleoconch whorls pagoda-like, with a slightly concave region between the suture and the shoulder. Whorls sculptured on their shoulder with large, axially elongated nodules that extend towards the lower suture, about 14 on the $8^{\text {th }}$ whorl, and numerous axial threads, stronger on the earlier whorls. Just below the suture there are many short curved axial riblets that do not reach the whorl shoulder. Suture moderately deep.
Base entirely sculptured with spiral threads. Labial sinus broad and moderately deep. Inner lip thin. Outer lip projecting forward. Siphonal canal very long and wide. Aperture elliptical.

Geographical distribution: Northwest Atlantic: North Carolina, Florida, West Indies (Dall, 1889; Dall, 1890), Colombian continental slope (Gracia et al., 2004, as L. verrilli). Southwest Atlantic: Rio de Janeiro (Dall, 1890; this paper).

Bathymetry: from $874 \mathrm{~m}$ (Dall, 1889) to $1609 \mathrm{~m}$ (Dall, 1890).

Discussion: Our material matches perfectly with the original illustration (Dall, 1889, pl. XXXVI, Fig. 5) and description (Dall, 1889, p. 76), though none of our specimens had a full protoconch to be illustrated here. This species can be distinguished from other species of Leucosyrinx by the extremely long siphonal canal and the short axial riblets below the suture.

\section{Leucosyrinx ? subgrundifera (Dall, 1888)} (Fig. 2F, G, H)

Pleurotoma (Leucosyrinx) subgrundifera Dall in Agassiz, 1888: 66, Fig. 283: Dall (1889: 77, pl. XXXVIII, Fig. 1).

Leucosyrinx subgrundifera: Powell (1966: 30); Abbott (1974: 263, Fig. 2900).

Type material: Syntype MCZ 007038, off Yucatan Strait, 1170 m (not examined).

Material examined: 16728 [2] OP I \# 13; 16705 [1] OP II \# 13-2; 18266 [1] OP I \# 75; 18267 [2] OP II \# 45; 18268 [2] OP II \# 59; 17270 [1] OP II \# 74.

Description: Shell high, slender, whitish, with 8 whorls (Fig. 2F, G). Protoconch with three whorls, dark yellow, first whorl smooth, subsequent whorls with a middle keel ornamented with pointed nodules, both gradually increasing in prominence (Fig. $2 \mathrm{H}$ ). This keel continues into the teleoconch where it becomes a large drooping flap on each whorl, forming a relatively extensive, almost straight region between the suture and the keel. The distal end of the keel is rounded, with vanishing nodules towards the body whorl. On the body whorl, the keel is a bit less prominent, and no longer points downwards but rather horizontally. Suture shallow. A rounded spiral cord marks the beginning of the base, which is smooth. Inner lip reflected. Labial sinus broad and deep. Siphonal canal narrow, very long. Aperture triangular-elongated.

Geographical distribution: Northwest Atlantic: North Carolina, Florida, West Indies (Dall, 1889). Southwest Atlantic: Campos Basin, southeast Brazil (this paper).

Bathymetry: from $749 \mathrm{~m}$ (this paper) to $1324 \mathrm{~m}$ (Dall, 1889). 
Discussion: Our material fits quite well with the original description of this species, but our shells have a larger profile compared with the original illustration by Dall (1889, pl. XXXVIII, Fig. 1).

Dall (1889, p. 75) created the genus Leucosyrinx and stated that "peripheral keel if present not recurved". In the same paper (Dall, 1889, p. 77), he described L. subgrundifera, which does not agree with his own genus concept, "in some cases having its edge actually curved forward and overhanging". In addition, Leucosyrinx is characterized by its spiral threads and the presence of nodules on the whorl shoulder. None of these characters is present in L. subgrundifera.

A few other turrid genera have an equally prominent keel as this species, such as Spirotropis Sars, 1878 and Cochlespira Conrad, 1865. However, although Spirotropis monterosatoi (Locard, 1897), the type species of Spirotropis (see Bouchet and Warén, 1980, p. 18, Fig. 57), has a high spire, narrow aperture, deep labial sinus, and the characteristic spiral keel, L. subgrundifera is distinguished by a longer siphonal canal and a blunt and slightly drooping keel, whereas in Spirotropis the siphonal canal is shorter and the keel is thinner and pointed upwards. Cochlespira has the keel, the elongated profile and the long siphonal canal, but the keel is also thin and pointed upwards, and it is ornamented with spines. In contrast, in L. subgrundifera the keel has barely perceptible small rounded nodules.

Ancistrosyrinx clytotropis (Sykes, 1906) as illustrated by Bouchet and Warén (1980, p. 24, Fig. 67) is probably congeneric with $L$. subgrundifera, because both share the same shell profile and type of keel. The genus Ancistrosyrinx, however, is very similar to $\mathrm{Co}$ chlespira, and is sometimes even regarded as its junior synonym (Abbott, 1974). Ancistrosyrinx elegans Dall, 1881 (illustrated in Dall, 1889, pl. 38, Fig. 3) is the type species of the genus and it has a sharp keel, pointed upwards and ornamented with spines, a feature that is quite different from what is observed both in our material and the shell illustrated as A. clytotropis by Bouchet and Warén (1980: p. 24, Fig. 67).

Powell $(1942 ; 1966)$ illustrated some genera that have a keel somewhat similar to that of L. subgrundifera, but not recurved, and either smooth (Tahusyrinx, Lirasyrinx) or moniliform (Cosmasyrinx). All of these genera, however, have spiral striation on the teleoconch, whereas $L$. subgrundifera, aside from the keel, has no sculpture at all. The genus Tatcherina Vera-Peláez, 1998 has a keeled teleoconch, but this keel is not nearly as projected, especially on the earlier whorls, and it also has spiral striation on the teleoconch. In addition, the protoconch is diagonally cancelled (Gracia and Vera-Peláez, 2004).

Although we do not agree with the assignment of subgrundifera to Leucosyrinx, we were unable to find a better generic allocation for it. Therefore, we have left it provisionally in the genus Leucosyrinx for now, simply to avoid the useless multiplication of synonyms, but a definitive generic allocation is pending on additional studies of soft parts.

\section{Subfamily DrilliInae Morrison, 1966 Genus Splendrillia Hedley, 1922}

Type-species: Drillia woodsi Beddome, 1883 by original designation.

\section{Splendrillia centimata (Dall, 1889)}

(Fig. 2I, J, K)

Drillia ? (Cymatosyrinx) centimata Dall, 1889: 95, pl. XXXVI, Fig. 9.

Pleurotoma centimata: Dautzenberg and Fischer (1906: 10).

Pleurotoma (Cymatosyrinx) centimata: Dautzenberg (1927: 31, pl. II, Fig. 10, 11).

Cymatosyrinx centimata: Powell (1966: 900).

Spirotropis centimata: Bouchet and Warén (1980: 20, Figs. 2, 54, 191, 203).

Type material: Syntype MCZ 007094, Blake sta 31, Gulf of Mexico (243'스. $\left.84^{\circ} 23^{\prime} \mathrm{W}\right), 3511 \mathrm{~m}$. (not examined).

Material examined: 16491 [1] OP I \# 1; 18265 [2, 1 live] OP I \# 2; 16737 [1] OP I \# 5; 16454 [2] OP I \# 8; 16486 [3] OP I \# 9; 16713 [2, 1 live] OP I \# 11; 16496 [2] OP I \# 12; 16502 [2] OP I \# 14; 16485 [2] OP I \# 15; 16404 [1] OP I \# 16; 16740 [9, 1 live] OP I \# $18 ; 16558$ [1 live] OP II \# 2; 16556 [2, 1 live] OP II \# 3; 18264 [1] OP II \# 5; 16385 [1] OP II \# 8; 16632 [1 live] OP II \# 11; 16624 [3, 1 live] OP II \# 12; 16654 [1] OP II \# 14; 16561 [5] OP II \# 16; 16648 [2] OP II \# 17-1; 16607 [2, 1 live] OP II \# 18; 18262 [2] OP II \#58; 18263 [1] OP II \#63.

Description: Shell high, slender, white, with 9 whorls (Fig. 2I, J). Protoconch with two whorls, yellow, smooth except for very fine suprasutural spiral threads (Fig. 2K). Teleoconch whorls pagoda-like, with a relatively short concave region between the suture and the shoulder. Whorls sculptured on their shoulders, with large, blunt and very prominent, axially elongated nodules on their lower half, about 14 on the $8^{\text {th }}$ whorl. Surface of the shell completely smooth aside from extremely faint growth lines. Suture shallow. Labial sinus broad, deep, and slightly tubular. Inner lip reflected. Outer lip projecting forward. Siphonal canal wide and short. Aperture elliptical.

Geographical distribution: Northwest Atlantic: North Carolina, Florida, Gulf of Mexico (Dall, 1889). Southwest Atlantic: Campos Basin, southeast Brazil (this paper). Northeast Atlantic: Azores and Morocco (Dautzenberg, 1927); Morocco (Dautzenberg and Fischer, 1906); Portugal, Morocco, Azores and Madeira (Bouchet and Warén, 1980)

Bathymetry: from $1122 \mathrm{~m}$ (this paper) to $3511 \mathrm{~m}$ (Dall, 1889).

Discussion: Hedley (1922) described Splendrillia as a subgenus of Melatoma Swainson, 1840, to include species with a "particularly glossy surface, and absence of the usual spirals". The genus Melatoma, originally considered a fluvial taxon, was transferred to Turridae by Dall (1918), and Clionella Gray, 1847 was considered as its synonym. These decisions, however, have not been generally accepted, and some authors 
(Powell, 1942; Iredale, 1918) have chosen to consider Clionella the valid name for the group until the matter is resolved. Either way, Splendrillia is very different from these genera, with a generally smaller size and a smooth protoconch with fine suprasutural spiral threads (Wells, 1990).

Splendrillia woodsi, the type species of Splendrillia (illustrated in Powell, 1966, pl. 12, Fig. 19), is quite similar to Cymatosyrinx lunatus (Lea, 1843) the type species of Cymatosyrinx (illustrated in Powell, 1966, pl. 13, Figs. 16-17) but differs from it by having a smooth protoconch, a very weak stromboid notch, and a fasciole that is not ridge-margined; whereas $C$. lunatus has a carinated protoconch, a deep stromboid notch, a nodulose subsutural cord and a prominent ridge edging the anterior fasciole (Powell, 1966).

Although it is very similar to Leucosyrinx verrilli (Dall, 1881) (illustrated in Dall, 1889, pl. X, Fig. 5), the type species of Leucosyrinx, since both share the macroscopically smooth protoconch and general outline of the shell, $L$. verrilli can be distinguished by a delicate sculpture of spiral keels or threads over the entire shell and usually a long anterior canal (Dall, 1889); whereas in $S$. woodsi the spiral sculpture is absent (some species of Splendrillia have such sculpturing restricted to the rostrum) and the anterior canal is short (Kilburn, 1988).

Dall (1889) described $S$. centimata in the genus Cymatosyrinx, which is characterized by several traits that are clearly absent in this species, such as a carinated protoconch, a deep stromboid notch, a nodulose subsutural cord and a prominent ridge edging the anterior fasciole. Bouchet and Warén (1980) transferred this species to the genus Spirotropis, but the genus Spirotropis (see Bouchet and Warén, 1980, p. 18, Fig. 57) has a completely smooth peripheral carina, aside from a very weak nodulation only on the earlier whorls; and $S$. centimata has very large blunt nodules on every whorl of the teleoconch. As such, this species seems to be better allocated to the genus Splendrillia, because it shows the typical smooth glossy surface, short siphonal canal, subtubular labial sinus, and strong, axially oriented nodules below the shoulder. Therefore, this fit with the concept of Splendrillia suggests that it is a better generic placement than Cymatosyrinx or Spirotropis.

\section{ACKNOWLEDGEMENTS}

Our best thanks to Dr. Adriana Gracia, Dr. Jesus Troncoso, Dr. Yuri Kantor and Dr. Gary Rosenberg for bibliographic help; to Dr. Anders Warén for discussing some of the species with us and for bibliographic help; to David Bolton for sending us photos of type material; to Dr. José Templado and two anonymous reviewers for their suggestions for improving the manuscript; to Petrobrás/SA for providing the material and the SEM images and to CNPq for partial support of this project.

\section{REFERENCES}

Abbott, R.T. - 1974. American Seashells. 2., pp. 663, 24 pls. Van Nostrand Reinhold Co., New York.

Absalão, R.S. and A.D. Pimenta. - 2003. A new subgenus and three new species of Brazilian deep waters Olivella (Mollusca, Gastropoda, Olivellidae) collected by the RV Marion Dufresne in 1987. Zoosystema, 25: 177-185.

Absalão, R.S. and F.N. Santos. - 2004. Recent deep-sea species of Benthonellania Lozouet, 1990 (Gastropoda, Rissoidea) from the South-Western atlantic with description of two new species utilizing a shell morphometric multivariate. J. Conchol., 38: 329-340.

Absalão, R.S, C. Miyaji, and A.D. Pimenta. - 2001. The genus Brookula Iredale, 1912 (Gastropoda: Trochidae) from Brazil: description of a new species, with notes on other South American species. Zoosystema, 23: 675-687.

Absalão, R.S., A.D. Pimenta and C.H.S. Caetano. - 2005. Turridae (Mollusca, Neogastropoda, Conoidea) coletados no litoral Sudeste do Brasil, Programa REVIZEE "score" central. Biociências, 13(1): 19-47.

Adams, H. and A. Adams. - 1858. The genera of recent Mollusca. Vol. I. Woodfall and Kinder, London.

Agassiz, A. - 1888. A contribution to American thalassography: Three cruises of the United States Coast and geodetic survey steamer "Blake", in the gulf of Mexico, in the Caribbean sea, and along the Atlantic coast of the United States, from 1877 to 1880. II. Bull. Mus. Comp. Zool., 15: 1-220.

Barros, J.C.N, S.F.B. Lima and J.A. Francisco. - 2007. Two new species of Aclis (Mollusca: Gastropoda: Aclididae) from the continental slope of northeast Brazil. Zootaxa, 1614: 61-68.

Bartsch, P. - 1934. New mollusks of the family Turritidae. Smithson. Misc. Collect., 91(2): 1-29, 8 pls.

Bouchet, P. and J.-P. Rocroi. - 2005. Classification and Nomenclator of Gastropod Families. Malacologia, 47 (1-2): 1-397.

Bouchet, P. and A. Warén. - 1980. Revision of the Northeast Atlantic bathyal and abyssal Turridae (Mollusca, Gastropoda). J. Molluscan Stud., Suppl. 8: 1-119.

Bouchet, P. - 1990. Turrid genera and mode of development: the use and abuse of protoconch morphology. Malacologia, 32(1): 69-77.

Castellanos, Z.J.A. and N.A. Landoni. - 1993. Catálogo descriptivo de la malacofauna magallánica. 11. Neogastropoda. Turridae. pp. 31. Comisión de Investigaciones Científicas de la Provincia de Buenos Aires, La Plata.

Dall, W.H. - 1881. Reports on the results of dredging, under the supervision of Alexander Agassiz, in the Gulf of Mexico, and in the Caribbean Sea, 1877-79, by the United States Coast Survey Steamer 'Blake'. Bull. Mus. Comp. Zool., 9: 33-144.

Dall, W.H. - 1889. Reports on the results of dredgings, under the supervision of Alexander Agassiz, in the Gulf of Mexico (187778 ) and in the Caribbean Sea (1879-80), by the U. S. Coast Survey Steamer 'Blake'. Bull. Mus. Comp. Zool., 18: 1-492, pls. $10-40$.

Dall, W.H. - 1890. Scientific results of explorations by the U. S. Fish Commission Steamer Albatross. No. VII.--Preliminary report on the collection of Mollusca and Brachiopoda obtained in 1887-'88. Proc. U. S. Natl. Mus., 12(773) 219-362, 5-14 pls. [Stated date: 1889; true date: 1890.]

Dall, W. H. - 1903. A preliminary catalogue of the shell-bearing marine mollusks and brachiopods of the Southeastern coast of the United States, with illustrations of many of the species. Reprint of Bull. U.S. Nat. Mus., 1889, 37: 1-232, pl. 1-95, with 21 additional plates.

Dall, W.H. - 1918. Notes on the nomenclature of the mollusks of the family Turritidae. Proc. U. S. Natl. Mus., 54 (2238): 313-333.

Dall, W.H. - 1919. Descriptions of new species of mollusks of the family Turritidae from the West coast of America and adjacent regions. Proc. U. S. Natl. Mus., 56 (2288): 1-86.

Dautzenberg, P. - 1927. Mollusques provenant des campagnes scientifiques du Prince Albert 1 de Monaco dans l'Océan Atlantique et dans le Golfe de Gascogne. Résultats des campagnes scientifiques accomplies sur son yacht par Albert 1 Prince Souverain de Monaco, 72: 1-400, 1-9 pls.

Dautzenberg, P. and H. Fischer. - 1906. Mollusques provenant des dragages effectués à 1'Ouest de l'Afrique pendant les cam- 
pagnes scientifiques de S. A. S. le Prince de Monaco. Résultats des campagnes scientifiques accomplies sur son yacht par Albert 1 Prince Souverain de Monaco, 32: 1-125, 1-5 pls.

Forcelli, D.O. - 2000. Moluscos Magallanicos Guia de Moluscos de Patagonia y Sur de Chile. Vazquez Mazzini Editores, Santiago.

Gracia, A.C. and J.L. Vera-Peláez. - 2004. Thatcherina diazi, nueva especie actual del género fósil del Plioceno Thatcherina VeraPeláez, 1998 (Gastropoda, Turridae) del Caribe Colombiano: consideraciones estratigráficas, biogeográficas y filogenéticas. Pliocénica 4: 1-10.

Gracia, A.C., N.E. Ardila and J.M. Díaz. - 2004. Gasterópodos colectados en el talud continental del Caribe colombiano durante las campañas INVEMAR-Macrofauna (1998-2001). Iberus, 22(1): 43-75.

Hedley, C. - 1922. A revision of the Australian Turridae. Rec. Aust. Mus., 13: 213-359, pls. XLII-LVI.

Iredale, T. - 1918. Molluscan nomenclatural problems and solutions, no. 1. Proc. Malacol. Soc. London, 13: 28-40.

Kilburn, R.N. - 1983. Turridae (Mollusca: Gastropoda) of southern Africa and Mozambique. Part 1. Subfamily Turrinae. Ann. Natal Mus., 25(2): 549-585.

Kilburn, R.N. - 1988. Turridae (Mollusca: Gastropoda) of southern Africa and Mozambique. Part 4. Subfamily Driliinae, Crassispirinae and Strictispirinae. Ann. Natal Mus., 29: 167-320.

Leal, J.H. and P. Bouchet. - 1989. New deep-water Volutidae from off southeastern Brazil (Mollusca: Gastropoda). Nautilus, 103: $1-12$.

Leal, J.H. and P. Bouchet. - 1991. Distribution patterns and dispersal of prosobranch gastropods along a seamount chain in the Atlantic Ocean. J. Mar. Biol. Ass. U.K., 71: 11-25.

Leal, J.H. and E.C. Rios. - 1990. Nanomelon vossi, a new deep-water Zidoninae from off southern Brazil (Gastropoda: Volutidae). Veliger, 33: 317-320.

Leal, J.H. and L.R.L. Simone. - 1998. Propilidium curumim, a new species of Lepetidae (Gastropoda, Patellogastropoda) from off southern and southeastern Brazil. Bull. Mar. Sci., 63: 157-165.

Leal, J.H. and L.R.L. Simone. - 2000. Copulabyssia riosi, a new deep-sea limpet (Gastropoda: Pseudococculinidae) from the continental slope off Brazil with comments on the systematics of the genus. Nautilus, 114: 59-68.

Lima, S.F.B. and J.C.N. Barros. - 2007. Two new species of Cerithiella (Apogastropoda: Cerithiopsidae) for the continental slope of Pernambuco (northeast Brazil). Zootaxa, 1441: 63-68.

Lima, S.F.B, J.C.N. Barros and R.E. Petit. - 2007. A new species of Gerdiella (Gastropoda: Cancellariidae) from the South Atlantic Ocean off Brazil with discussion of an undescribed species. Nautilus, 121: 99-103.

Lundberg, J., C. Schander and Ø. Stockland. - 1996. A preliminary cladistic analysis of North Atlantic Oenopota Moerch, 1852 and Propebela Iredale, 1918 (Gastropoda: Conoidea). J. Molluscan Stud., 62: 289-298.

Medinskaya, A.I. - 1999. Foregut anatomy of the Cochlespirinae (Gastropoda, Conoidea, Turridae). Zoosystema, 21(2): 171-198.

Powell, A.W.B. - 1942. The New Zealand recent and fossil Mollusca of the family Turridae. With general notes on turrid nomenclature and systematics. Bull. Auckl. Inst. Mus., 2: 1-192.

Powell, A.W.B. - 1966. The molluscan families Speightiidae and Turridae. An evaluation of the valid taxa, both recent and fossil, with lists of characteristic species. Bull. Auckl. Inst. Mus., 5: $1-184$.

Puillandre, N., S. Samadi, M.-C. Boisselier, A.V. Sysoev, Y.I. Kantor, C. Cruaud, A. Couloux and P. Bouchet. - 2008. Starting to unravel the toxoglossan knot: molecular phylogeny of the "turrids" (Neogastropoda: Conoidea). Mol. Phylogenet. Evo., 47: 1122-1134.

Rios, E.C. - 1975. Brazilian Marine Mollusks Iconography, pp. 331, 91 pls. Fundação Universidade do Rio Grande, Rio Grande.

Rios, E.C. - 1985. Seashells of Brazil. Fundação Universidade do Rio Grande, Rio Grande.

Rios, E.C. - 1994. Seashells of Brazil. 2. Fundação Universidade do Rio Grande, Rio Grande.

Rosenberg, G. - 1998. Reproducibility of results in phylogenetic analysis of mollusks: a reanalysis of the Taylor, Kantor, and Sysoev (1993) data for conoidean gastropods. Am. Malacol. Bull., 14(2): 219-228.

Rosenberg, G. - 2005. Malacolog 4.1.0: A Database of Western Atlantic Marine Mollusca. [WWW database (version 4.1.0)] URL http://www.malacolog.org/.

Simone, L.R.L. - 1999. The anatomy of Cochlespira Conrad (Gastropoda, Conoidea, Turridae) with a description of a new species from the Southeastern coast of Brazil. Rev. Bras. Zool., 16: 103-115.

Simone, L.R.L. - 2002. Thee new deepwater species of Eulimidae (Caenogastropoda) from Brazil. Novapex, 3: 55-60.

Simone, L.R.L. - 2003. Revision of the genus Benthobia (Caenogastropoda, Pseudolividae). J. Molluscan Stud., 69: 245-262.

Simone, L.R.L. and A. Birman. - 2006. A new species of Iphinopsis (Caenogastropoda, Cancellariidae) from Brazil. J. Conchol., 39: 141-144.

Simone, L.R.L. and C.M. Cunha. - 2006. Revision of genera Gaza and Callogaza (Vetigastropoda, Trochidae), with description of a new Brazilian species. Zootaxa, 1318: 1-40.

Taylor, J.D., Y.I. Kantor and A.V. Sysoev. - 1993. Foregut anatomy, feeding mechanisms, relationships and classification of the Conoidea (= Toxoglossa) (Gastropoda). Bull. Nat. Hist. Mus. Zool., 59(2): 125-170.

Thiele, J. - 1925. Gastropoda der Deutschen Tiefsee-Expedition. II. Teil. Wissenschaftliche ergebnisse der deutschen Tiefseeexpedition auf dem dampfer 'Valdivia', 1898-1899, 17(2): 35382 [1-348], pls. XIII-XLVI [I-XXXIV].

Thiele, J. - 1931. Handbuch des Systematisches Weichtierkunde Vol. I., pp. vi + 1-778. Jena Verlag von Gustav Fischer, Germany.

Tucker, J.K. - 2004. Catalog of recent and fossil turrids (Mollusca: Gastropoda). Zootaxa, 682: 1-1295.

Wells, F.E. - 1990. Revision of the recent Australian Turridae refered to the Genera Splendrillia and Austrodrillia. J. Malacol. Soc. Aust., 11: 73-117.

Zelaya, D.G., R.S. Absalão, and A.D. Pimenta. - 2006. A revision of Benthobrookula Clarke, 1961 (Gastropoda, Trochoidea) in the Southwestern Atlantic Ocean. J. Molluscan Stud., 72: 77-87.

Scient. ed.: J. Templado.

Received May 4, 2009. Accepted November 10, 2009.

Published online May 14, 2010. 